\title{
ROMA SZAKKOLLÉGISTÁK HAJDÚ-BIHAR MEGYÉBEN
}

Szerzők:

Rákó Erzsébet (Ph.D)

Debreceni Egyetem (Magyarország)

Bocsi Veronika (Ph.D)

Debreceni Egyetem (Magyarország)

E-mail address:

rakoe@ped.unideb.hu
Lektorok:

\author{
Ceglédi Tímea (Ph.D) \\ Debreceni Egyetem (Magyarország) \\ Kerülő Judit (Csc.) \\ Nyíregyházi Egyetem (Magyarország) \\ ...és további két anonim lektor
}

Rákó Erzsébet, Bocsi Veronika (2020). Roma szakkollégisták Hajdú-Bihar megyében. Különleges Bánásmód, 6. (4). 41-60. DOI $10.18458 /$ KB.2020.4.41

\begin{abstract}
Absztrakt
A tanulmány fó célja, hogy a debreceni székhellyel múködő roma szakkollégiumokban tanuló diákokat bemutassa. Ennek keretét egy 2019-es kutatás adja, amely a három szakkollégium 62 hallgatóját érte el. A téma aktualitását az adja, hogy a roma és nem roma fiatalok továbbtanulását összevetve még mindig kevés a felsőoktatásba bekerülő roma fiatalok száma. Arra a kérdésre kerestük a választ, hogy milyen tényezők segítették a roma szakkollégistákat az iskolai sikerek elérésben. A kutatás kérdőíve a diákok szociokulturális hátterét, tanulási motivációit, középiskolai tapasztalatait, illetve a kapcsolathálók etnikai mintázatait mérte fel. Az empirikus eredmények elméleti kereteit a magyarországi roma gyermekek és fiatalok oktatásszociológiai kutatásainak eredményei jelentik, amelyeket a felzárkóztató programok ismertetésével egészítünk ki. Az elemzés során a kapott adatokat a Magyar Ifjúság 2016 adatbázisához viszonyítjuk, így képet kapunk arról, hogy a roma fiatalok milyen csoportjai számára vált elérhetővé a felsőoktatás. Vizsgálatunk egy szála a roma identitással bíró, illetve roma identitással nem bíró szakkollégisták összehasonlítását tartalmazza.
\end{abstract}

Kulcsszavak: Felsőoktatás, roma hallgatók, egyenlőtlenségek

Diszciplína: szociológia, szociálpolitika

\begin{abstract}
:
STUDENTS FROM ROMA COLLEGES FOR ADVANCED STUDIES IN HAJDÚ-BIHAR COUNTY

The main objective of the paper is to present students who are members of those kinds of Roma Colleges for Advanced Studies which headquarters can be found in Debrecen. The frame of the study is in connection with research that has been carried out in 2019 and dealt with three Colleges for Advanced
\end{abstract}


Studies with 62 students. The relevance of the topic is given by the fact that by comparing Roma and nonRoma students' ratio in tertiary education, we can recognize the phenomenon that the proportion of Roma students is still lower. We sought an answer to the question of what factors helped Roma students to achieve success in school. The research questionnaire assessed students' socio-cultural background, learning motivation, high school experiences, and the ethnic patterns of networks. The theoretical framework of the empirical results is the outcome of the sociological researches that focus on Hungarian Roma children's educational situation. These were supplemented by the description of the development programs. In the course of analysis, we compare the obtained data with the database of the Hungarian Youth 2016, as a consequence that, we get an idea of the groups of Roma youth for whom tertiary education has become available. One of our research targets includes the comparison of students with or without Roma identity.

Keywords: higher education, gipsy- roma students, inequalities, college for advanced studies

Diszcipline: sociology, social politics

\section{Elméleti keretek}

Magyarországon a roma gyermekek alapfokú iskoláztatása csak a hatvanas években jelenik meg a párthatározatok szintjén (Forray és Hegedús, 2001), s a folyamat csupán lassan és számos nehézséggel indul. Az alapfokú oktatásban való részvételüket sok esetben szegregált intézmények, eltérô tantervek és a kisegítő osztályok jellemezték. A hazai reprezentatív roma-vizsgálatok rámutatnak a romák alacsonyabb iskolai végzettségére (Kemény, Janky és Lengyel, 2004), amely ugyan javuló tendenciát mutat, de mindig messze elmarad a nem roma lakosság iskolázottságától (Szabóné Kármán, 2008). Ha a magyar oktatási rendszer szelektivitásából indulunk ki, akkor joggal mondhatjuk, hogy a roma gyermekek, akiknek halmaza nem egyenlő a hátrányos helyzetú gyermekek halmazával, de azzal komolyabb átfedést mutat, „elvesznek” a közoktatás elágazási pontjain, s az iskolai karrierjük csak a legritkább esetben vezet a felsőoktatásig. Azonban arról sem szabad megfeledkeznünk, hogy az utóbbi évek kitermeltek vagy támogattak olyan intézménytípusokat, oktatási programokat és felzárkóztató programokat, amelyekkel a roma fiatalok iskolai esélyei (is) növelhetők (tanodák, ösztöndíjak rendszere, átfogó intézményi programok stb.). Ezek hatásvizsgálatainak felmérése az utóbbi idôszakban el is kezdôdött (pl. Györgyi, 2015). A felsőoktatásba bejutó roma hallgatók szervezeti háttereként megjelentek a roma szakkollégiumok, amelyek egy része felekezeti fenntartású. A diplomás roma értelmiség kibővitése, létszámának emelése kiemelten fontos terület. A végzett fiatalok egyrészt mintaadó szereppel bírhatnak a lokális közösségekben, másrészt a különböző oktatási, nevelési, gyermekjóléti intézmények múködésének a hatásfokát tudják jelentősen megemelni.

\section{Roma gyermekek a közoktatásban}

A következőkben - a teljesség igénye nélkül áttekintjük azokat a kutatásokat, amik ez elmúlt néhány évben a roma gyerekek oktatásával foglalkoznak különös tekintettel a középiskolai és 
felsőoktatási tanulmányokra. Liskó Ilona az 1999/2000-es tanévben vizsgálta a roma tanulók oktatásának körülményeit az általános iskolákban. A kutatás mintájába 192 általános iskola került be, ahol a 6. osztályos roma gyerekek szüleinek (1779 fö) iskoláztatási aspirációit tárta fel. A kapott válaszok szerint a szülők 22\%-a szeretné, ha a gyermeke érettségit adó középiskolában, 57\%-a pedig, ha a gyermeke szakmunkásképzőben tanulna tovább (17\%-uk még bizonytalan volt a továbbtanulást illetően, 4\%-uk pedig nem tervezett továbbtanulást). Ezek az iskoláztatási tervek összhangban vannak azokkal a tapasztalatokkal, amelyek szerint az általános iskolát elvégző roma gyerekek évről évre nagyobb arányban kerülnek be valamilyen középfokú iskolába. Ugyanennek a kutatásnak az általános iskolák igazgatóitól származó információi szerint az 1998/99-es tanévben az általános iskola elvégzése után a roma tanulók 57\%-a tanult tovább szakmunkásképzőben, 15\%uk szakközépiskolában, 9\%-uk szakiskolában és 4\%-uk gimnáziumban. Mindössze 15\%-uk maradt ki a középfokú továbbtanulásból. (Liskó, 2002) Egy további kutatásban Liskó (2005) kérdőíves adatfelvételre került sor 2003-ban olyan roma és nem roma középiskolások körében, akik szakmai iskolák mellett működő kollégiumokban laktak. Összesen 191 ilyen kollégium 10. osztályos tanulóit vizsgálták, 1588 tanuló megkérdezésére került sor. A kutatás eredményei közül elsősorban a családi körülmény, a pályaválasztás, a középiskolai továbbtanulás és a kollégiumi elhelyezésre vonatkozókat mutatjuk be. A kutatás szerint a gyerekek társadalmi hátrányainak egy része a falusi lakóhelyből, a szülők alacsony iskolai végzettségéből, munkanélküliségéből fakad, a roma tanulók társadalmi mobilitását azonban nem csak a falusi lakóhely, hanem a családok felbomlása ill. a szülők elvesztése is nehezíti. Mivel a szülők generációjában még igen gyakori volt a rendkívül fiatalon, szinte gyerek fejjel (14-16 évesen) történő házasságkötés, ill. családalapítás, meglehetősen gya- korinak számít az együttélések felbomlása. 2005ban azt tapasztaltuk, hogy a roma tanulóknak mindössze a 86\%-a élt együtt az édesanyjával, és 62\%-a az édesapjával. A hátrányos helyzetű roma tanulók gyenge iskolai eredményeit a pedagógusok igen gyakran alacsony tanulási motivációjukkal, vagy a motiváltság hiányával magyarázzák. Az alacsony motivációs szint egyik fontos oka gyakran az, hogy a gyerekek családi, ismeretségi, és lakóhelyi környezetében nincsenek olyan mobilitási modellek, amelyek számukra mintát szolgáltathatnának. Az idősebb testvér annak ellenére, hogy a felnőtt testvérek generációja már a szülőkhöz képest kétségtelenül lényegesen előbbre jutott az elvégzett iskolai évek számában, a gyakran félbehagyott szakmatanulással és a megszerzett iskolázottság gyenge hasznosulásával korántsem jelent követendő mintát (vagyis határozott továbbtanulási motivációt) a kisebb testvérek, vagyis a jelenleg középiskolás roma tanulók számára. A kutatás kitért a pályaválasztás kérdésére is, ahol az derül ki, hogy a konkrét iskola és a konkrét szakma kiválasztásához azonban többségük lényegében semmilyen felnőtt segítségre nem számíthatott.

Liskó (2005) megállapította, hogy a roma középiskolások általában olyan iskolákba és szakmákra kerülnek, ahova kevesen jelentkeznek. A gyerekek véletlenszerūen a környékbeli iskolák kínálata alapján döntenek, az eredeti elképzeléseiket sokszor kerülőkkel tudják csak megvalósítani.

A roma gyerekek jó része kollégiumi elhelyezést igényel a középiskolai tanulmányai idején. A nem roma tanulókkal ellentétben, akiknek 91\%-a kerül kollégiumba az iskolától távoli lakóhelye miatt, a roma tanulók közül háromszor annyian indokolták a bentlakást családjuk rendezetlenségével és majdnem hétszer annyian családjuk hiányával. Vagyis a kollégium a roma középiskolások esetében sokkal nagyobb felelősséget visel a szülői törődés és a család pótlásában, mint a nem roma tanulók esetében. Az általános iskolából kikerülő vidéki gyerekek számára a középiskolába kerülést a kollégiumi élet 
szokatlansága is nehezíti. A roma tanulók ebben a tekintetben is nehezebb adaptációs folyamatot élnek át társaiknál. Az ő esetükben nem csak a középiskolát, a városi környezetet és a kollégiumot kell megszokni, hanem az állandó többségi környezetet is, és azokat a középosztályi elvárásokat és szokásokat is, amelyeket családi környezetükben nem volt alkalmuk megismerni. A bizonytalanság és a félelem sok esetben nem csak a gyerekek, hanem a szülők állapotára is jellemző volt. (Liskó, 2005)

A TÁRKI roma fiatalok körében végzett kutatást, az Életpálya felmérés 2006-2012 között zajlott - több mint 7000 fiatal bevonásával. Az egyes években a családszerkezet, az anyagi helyzet, a tanulók kisgyermekkora, egészség-, iskolatörténete valamint a középiskolai továbbtanulás továbbá a középiskolai pályafutás, a lemorzsolódás és az egyetemi továbbtanulás került fókuszba. Liskó (2002) eredményeihez hasonlóan Kertesi és Kézdi (2008) is azt találta a TÁRKI-Educatio Életpálya felmérésben, hogy a roma és nem roma tanulók továbbtanulása jelentősen különbözik az iskolaválasztás tekintetében. „A nyolcadik osztály elvégzése után a roma tanulók 8\%-a nem tanul tovább, szemben a nem roma tanulók 1\%-ával. A roma tanulók 58\%-a tanul tovább szakiskolában, szemben a nem roma tanulók 23\%-ával; 26\%-uk tanul tovább szakközépiskolában, 8\%-uk pedig gimnáziumban (nem roma társaiknál ezek az arányok 42, illetve 34\%-osak). Érettségit adó középiskolában tanul tehát tovább a nem roma fiatalok háromnegyede, míg a roma fiataloknak alig több mint egyharmada." (Kertesi-Kézdi, 2008. 359.)

Az iskolaválasztásnak megfelelően a megszerzett középiskolai végzettség típusában is jelentősek a különbségek: míg a nem roma fiatalok között a legtöbben gimnáziumot végeznek és a korosztálynak kevesebb, mint egyötöde végez szakiskolát, addig a roma fiatalok között a szakiskola messze a leggyakoribb középiskolai végzettség. (KertesiKézdi, 2016) Fehérvári (2018) az Arany János Pro- gramok tanulói körében végzett kutatásában megállapította, hogy társadalmi csoportok szerint különböznek a továbbtanulási tervek. Az alsó társadalmi csoportokba tartozó gyerekek inkább választják a szakközépiskolai továbbtanulást, míg a középső és felső társadalmi csoportok között a különbséget abban látja, hogy a középső csoportnál nagyobb a szakgimnázium érettségi megszerzésére való törekvés.

A cigány és nem cigány tanulók továbbtanulási terveit összevetve Kertesi-Kézdi (2008) kutatásához hasonlóan különbséget talált. A továbbtanulási preferenciák a cigány származásúaknál eltolódnak az alacsonyabb presztízsú képzések felé. (Fehérvári, 2018)

\section{Roma fiatalok a felsöoktatásban}

A korábban bemutatatott TÁRKI roma fiatalok körében végzett kutatás, az Életpálya felmérés 2012-es hullámában a középiskolai továbbtanulás és az egyetemi tanulmányok kerültek fókuszba. A kutatás keretében két születési évjárat iskolai pályafutását hasonlították össze az általános iskola elkezdésétől a felsőoktatási tanulmányok megkezdéséig. Az egyik az 1971-ben születettek, a másik a 1991-ben születettek kohorsza. „A vizsgált két évtized alatt a roma fiatalok iskoláztatásában bámulatos mértékủ fejlődés történt: az általános iskolai lemorzsolódás minimálisra (23\%-ról 7\%-ra) szorult vissza, a középiskolába beíratottak aránya pedig 23\%-ról csaknem 90\%-ra emelkedett.

Mindez tükröződött a középiskolai végzettségek sikeres megszerzésében is. Amíg az 1971-ben született roma kohorsznak minimális esélye volt középfokú végzettséghez jutni - 14\%-nak volt szakiskolai végzettsége, és 1\%-nak érettségije -, addig a rendszerváltás után született generáció egynegyedének van ma már szakiskolai végzettsége, és több mint egyötödének érettségije." (Hajdu-KertesiKézdi, 2014, 271.) 
1. ábra. Az 1971-ben és 1991-ben született roma fiatalok iskolai pályafutása 20/21 éves életkorukban. Forrás: Hajdu, Kertesi és Kézdi, 2014. 270.

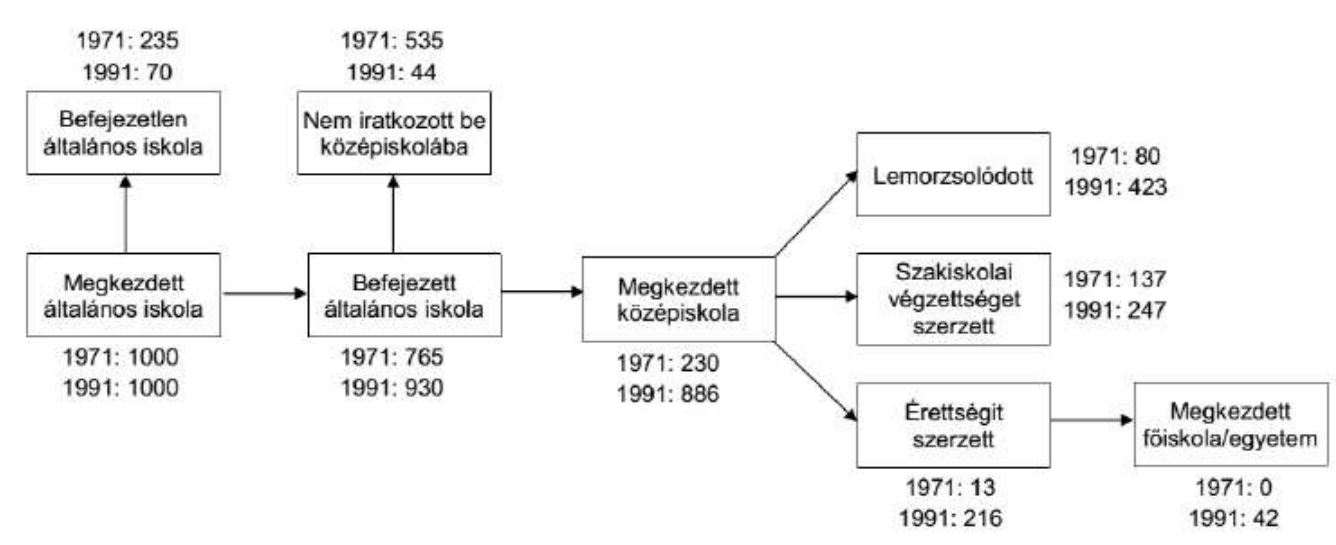

A kutatók két trendet látnak kirajzolódni, egyrészt az általános iskola sikeres befejezésében és a középiskolai továbbtanulásban jelentős mértékú felzárkózás történt; az érettségi megszerzésének esélyében és a felsőoktatási részvételben pedig tovább növekedett a leszakadás a társadalom átlagához képest. (Hajdu, Kertesi és Kézdi, 2014)

„Az érettségi eredményekben tapasztalható lemaradás következményekkel jár az egyetemi továbbtanulásra is. Miközben 20/21 éves korára csaknem minden második érettségizett nem roma fiatal felsőfokú tanulmányokat folytat, addig az érettségizett roma tanulók közül csupán minden ötödik jár főiskolára vagy egyetemre ebben az életkorban. E jelentős etnikai különbség csaknem kétharmada az érettségi eredmények különbségeire vezethető vissza, - ami, az előzőekből következő módon, ismét a középiskolát megelôző tényezők fontosságára hívja fel a figyelmet.” (Hajdu, Kertesi és Kézdi, 2014, 300.)

A középiskola utáni továbbtanulásra vonatkozóan Fehérvári (2018) az Arany János Programban tanulók körében azt találta, hogy magas a to- vábbtanulási hajlandóság. Az ATP programban tanulók döntő többsége tervezi, hogy felsőoktatásban tanul. A programban tanulók többsége úgy véli, hogy a program javítja a továbbtanulási esélyeit. A megkérdezettek 12-15 százaléka szerint a program nélkül nem lett volna esélye a továbbtanulásra.

\section{Középiskolai tanulmányokat segitö programok}

A középiskolai tanulást különböző esélynövelő szolgáltatásokkal próbálják segíteni. Az egyik ilyen az Arany János Programok köre. Az Arany János Programokra vonatkozóan több kutatás valósult meg az elmúlt években. A programok három típusát különböztetik meg. Az Arany János Tehetséggondozó Programot, az Arany János Kollégiumi Programot és az Arany János KollégiumiSzakközépiskolai Programot (Szemenyei, 2018). Mindhárom program célja, hogy a hátrányos helyzetủ tanulók hátrányait kompenzálja. Az Arany János Programok főbb jellemzőit a 2. táblázat foglalja össze. 
A három alprogramot elemezve Fehérvári (2018) megállapította, hogy az alprogramokban tanuló diákok jelentősen eltérnek családi hátterük, egyéni jellemzőik, iskolai útjuk és terveik tekintetében is. A Tehetséggondozó Programba járók családi háttere a legkedvezőbb, körükből kerül ki a legkevesebb alacsonyan iskolázott szüló, míg a Kollégiumiszakközépiskolai Programba járókénál a kétharmadot is meghaladja az arányuk. A roma tanulók közül a legtöbben a Kollégiumi Programba vesznek részt, közel hasonló arányban a Kollégiumi-
Szakközépiskolai programban, legkevesebben a Tehetséggondozó programban vannak jelen (Fehérvári, 2018).

Az elmúlt években tovább javult a romák iskolázottsági mutatója, de még mindig jelentős törésvonal van a romák és nem romák iskolázottsága között. Ez a különbség az oktatás minden szintjén megjelenik, de kiugró a felsőoktatás tekintetében (Hajdu, Kertesi és Kézdi, 2014; Bernát, 2018).

2. táblázat Az. Arany János Tehetséggondozó Programok föbb jellemzói. Forrás: Hives, 2018, 93.

\begin{tabular}{|c|c|c|c|}
\hline & $\begin{array}{l}\text { Arany János Tehetség- } \\
\text { gondozó Program }\end{array}$ & $\begin{array}{c}\text { Arany János Kollégiumi } \\
\text { Program }\end{array}$ & $\begin{array}{l}\text { Arany János Kollégiumi- } \\
\text { Szakközépiskolai Program }\end{array}$ \\
\hline Elindulás éve & $2000 / 2001$ & $2004 / 2005$ & $2006 / 2007$ \\
\hline Programszám & 23 & 11 & 7 \\
\hline Tanulólétszám & 2508 & 921 & 428 \\
\hline Érintett tanulók & $\begin{array}{r}24 \% \text { HH vagy } \mathrm{HHH} \\
76 \% \text { egyéb szociálisan } \\
\text { rászoruló }\end{array}$ & $\begin{array}{r}48,4 \% \mathrm{HHH}, \\
33,2 \% \mathrm{HH}\end{array}$ & $74,3 \% \mathrm{HHH}, 17,1 \% \mathrm{HH}$ \\
\hline Bekerülés & Felvételi bementi mérés & Jelentkezés a programba & Jelentkezés a programba \\
\hline $\begin{array}{l}\text { Tanulói támogatás } \\
\text { oktatásszervezés }\end{array}$ & $\begin{array}{r}5 \text { év gimnázium és kol- } \\
\text { légium közös tanulói } \\
\text { csoportban }\end{array}$ & $\begin{array}{r}\text { Előkészítő év és } 5 \text { év } \\
\text { közös kollégiumi csoport- } \\
\text { ban }\end{array}$ & $\begin{array}{r}\text { Szakmaszerzésig közös kol- } \\
\text { légiumi csoportban }\end{array}$ \\
\hline $\begin{array}{l}\text { Intézményi } \\
\text { támogatási forrás }\end{array}$ & Gimnázium és kollégium & $\begin{array}{l}\text { Előkészítő évet szervező } \\
\text { intézmény és kollégium }\end{array}$ & $\begin{array}{r}\text { Szakközépiskola és kol- } \\
\text { légium }\end{array}$ \\
\hline Kimenti cél & $\begin{array}{r}\text { Felsőoktatási felvétel } \\
(67 \% \text { továbbtanul, } 12 \% \\
\text { dolgozik) }\end{array}$ & $\begin{array}{l}\text { Érettségi ( } 57 \% \text { tovább- } \\
\text { tanul, } 41 \% \text { dolgozik) }\end{array}$ & $\begin{array}{l}\text { Szakmaszerzés ( } 36 \% \text { to- } \\
\text { vábbtanul, } 45 \% \text { dolgozik) }\end{array}$ \\
\hline Szakmai támogatás & $\begin{array}{r}\text { EMMI, Szakmai Ta- } \\
\text { nácsadó Testület és } \\
\text { AJTP Egyesület }\end{array}$ & $\begin{array}{r}\text { EMMI szakmai Tanácsadó } \\
\text { Testület és Mentori } \\
\text { Hálózat }\end{array}$ & $\begin{array}{l}\text { EMMI szakmai Tanácsadó } \\
\text { Testület és Mentori Hálózat }\end{array}$ \\
\hline
\end{tabular}




\section{Roma szakekollégiumok}

A szakkollégiumok között legkorábban a Wlislocki Henrik Szakkollégium kezdte meg tevékenységét, azzal a céllal hogy összefogja és integrálja a Pécsi Tudományegyetem különböző karain tanuló roma/cigány származású diákokat. 2011-ben létrejött a Keresztény Roma Szakkollégiumi Hálózat a (KRSZH). Ebben az évben már kilenc Roma Szakkollégium müködött Magyarországon, közülük hat egyházi és három nem egyházi fenntartásban. A kilenc szakkollégium összesen 235 hallgatót vett fel a 2014/2015-ös tanévben. 2015ben bővült a szakkollégiumok száma kettővel így 2016-ban már tizenegy Roma Szakkollégium müködött. (Internet 1)

A Roma Szakkollégiumi Charta alapelvei között a szakmaiság, a tehetséggondozás, a társadalmi felzárkózás és a közösség elve jelenik meg. A szakmaiság keretében minden szakkollégium saját szakmai programot dolgoz ki. A tanulmányi program elemei fejlesztik a hallgatók önértékelését, identitását, egyéni és szociális készségeket. A cél, magyar-cigány kettős identitással rendelkező öntudatos, pozitív szemléletű, roma értelmiség képzése, akik képesek aktív közéleti szerepvállalásra, társadalmi felelősségvállalásra. A tehetséggondozás keretében a felsőoktatásban tanulók tehetségének kibontakoztatása, a társadalmi felzárkózás keretében a hátrányos helyzetű hallgatók hátránykompenzálása valósul meg. A közösség elve szerint pedig a cigány és nem cigány hallgatók integrált tanulóközösséget alkotnak, egy öntevékeny együttlakó közösség keretében (Roma Szakkollégiumi Charta). A szakkollégiumi hallgatók havonta teljesítményhez kötött ösztöndíjban részesülnek. Mentorok, tutorok segítik őket mind a tanulásban, mind a felsőoktatási szocializációban. A tanulást kiegészítő/segítő programok mellet kutatásokba is bekapcsolódnak. Lehetőségük van különböző szakmai programokon, konferenciákon részt venni. Fontos program elem a nyelvtanulási lehetőség. A kutatásban három szakkollégium hallgatóit kér- deztük meg, a következőkben a szakkollégiumok célkitűzéseit tekintjük át: A Lippai Balázs Roma Szakkollégium 2012-ben jött létre a Debreceni Egyetem Gyermeknevelési és Felnőttképzési Karán (jelenleg Gyermeknevelési és Gyógypedagógiai Kar) és szoros együttmúködést alakított ki a Keresztény Roma Szakkollégiumi Hálózat (KRSZH) tagjaival. A Lippai Balázs Roma Szakkollégium alapvető célkitűzése, hogy hozzájáruljon a közéleti feladatok iránt elkötelezett, aktív társadalmi párbeszédet kezdeményező és folytató sikeres értelmiségiek formálódásához, a roma tehetséggondozásban szerepet vállaljon. Célunk olyan roma és magyar fiatalok egyéni, valamint közösségi képzése a felsőoktatásban, akik a személyre szabott mentorálás és a sokrétű kompetenciafejlesztés eredményeként elérhető szakmai kiválóságot ötvözik a társadalmi és szociális kérdések iránti érzékenységgel

A Wáli István Református Cigány Szakkollégium 2011-ben jött létre a Keresztény Roma Szakkollégiumi Hálózat (KRSZH) alapító tagja. A roma szakkollégium célja a szakmai programban megfogalmazottak szerint a következő: ,a program elemei fejlesztik a hallgatók személyiségét, identitását, szociális készségeit, és hozzájárulnak a kiemelkedő tudományos teljesítményhez. Segít elsajátítani azokat a kompetenciákat, melyek nélkülözhetetlenek a sikeres társadalmi mobilitáshoz. A szakkollégium keretében megvalósuló program célja, hogy a szakkollégisták a magyar és a cigány kultúrát egyaránt ismerő és értékelő, a cigányság sorsával kapcsolatban felelősen és autonóm módon gondolkodó, öntudatos, pozitív szemléletű, értelmiségivé váljanak, akik lehetőség szerint képesek aktív közéleti szerepvállalásra, előítéletektől mentesen, valódi közösséget tudnak építeni." (Wáli István Református Cigány Szakkollégium, Szakmai Program, 7.)

A Keresztény Roma Szakkollégiumi Hálózat (KRSZH) hatodik intézményeként alakult meg 2015 nyarán a Szent Miklós Görögkatolikus Roma Szakkollégium Debrecenben. A KRSZH tagjaként 
a szakkollégium azzal a céllal jött létre, hogy szakmai programjával és eszköztárával megteremtse azokat a feltételeket, amelyek optimálisan segítik a romákat érintő társadalmi problémákra érzékeny, keresztény értékrendet megtartó, sokoldalúan képzett fiatal értelmiség nevelését. A Szakkollégium kiemelt feladata és céljai között szerepel, olyan roma és magyar fiatalok, közösségi illetve egyéni szintű képzése a felsőoktatásban, akik képesek lesznek szakmai párbeszédeket folytatni, lokális közösségekben, a társadalmi integráció és felzárkózás ügyének élére állni és aktív szerepet vállalni.

\section{Módszertani keretek}

A roma szakkollégistákat leíró kutatás 2019 tavaszán zajlott, az összesen 92 hallgató közül 67 fö részvételével. A diákok a három Hajdú-Bihar megyei szakkollégium tagjai voltak (Lippai Balázs Roma Szakkollégium, Szent Miklós Görögkatolikus Roma Szakkollégium és Wáli István Református Cigány Szakkollégium - a szakkollégiumok tagjainak létszáma 37, 29 és 26 fő, közülük 23, 18 és 26 fő válaszolt.). Mivel mind a három szakkollégium székhelye Debrecen, s a megkérdezettek kivétel nélkül a Debreceni Egyetem hallgatói, ezért az általunk kapott eredmények nem reprezentálhatják a roma szakkollégisták alapsokaságát, hiszen a populáció alacsony elemszáma nem teszi lehetôvé a nagyobb létszámú kvantitatív elemzéseket, viszont fontos támpontokat adhatnak. A kapott eredmények értelmezésénél azt a tényt is szem elött kell tartani, hogy a Debreceni Egyetem a hallgatói összetételét tekintve speciális, hiszen országos viszonylatban a nagy egyetemek között itt a legmagasabb a hátrányos helyzetűek aránya (Hegedûs, 2018). A Debreceni Egyetem képzési struktúrája is speciális, hiszen a régió férfi hallgatóit inkább más intézmények szívják el, így a nők aránya magasabb. Az intézmény beiskolázási körzetét az ország leghátrányosabb helyzetû régiói adják. Ezek a tények minden bizonnyal a roma szakkollégisták arányát és jellegzetességeit is alakítják. A másik tényező, ami az általánosítást megakadályozza, a roma populáció heterogenitása.

A saját szerkesztésú kérdőív 57 kérdést tartalmazott, és a szociokulturális háttérváltozókon kívül felmérte a továbbtanulási motivációkat, az alapfokú és a középfokú oktatásban szerzett tapasztalatokat (erőforrások, korlátok), illetve az elérhető külső erőforrásokat (pályázatok, ösztöndíjak, szakemberek által nyújtott segítség).

Az alacsony elemszám miatt főleg leíró statisztikákat alkalmaztunk, ugyanakkor bizonyos esetekben a keresztkapcsolatokat is megvizsgáltuk (khínégyzet statisztikával vagy ANOVA teszttel). Ezeket az eredményeket fenntartásokkal érdemes kezelni. A keresztkapcsolatokat egyrészt roma identitással bíró és nem bíró diákok között, másrészt a szakkollégiumok relációjában vizsgáltuk. Bizonyos esetekben a Magyar Ifjúság 2016 adatbázishoz hasonlítottuk az eredményeket. (Megjegyzés: az adatbázis használati jogát a Kutatópont biztosította a számunkra -https://kutatopont.hu/).

A kapott adatokat az alábbi referenciacsoportokhoz viszonyítjuk: egyrészt magyar fiatalok adataihoz, másrészt a roma fiatalok adataihoz (megjegyzés: tisztában vagyunk azzal a ténnyel, hogy a szakkollégium nem csak roma identitású/származású fiatalokat fogad be), harmadrészt pedig a hazai egyetemista-főiskolás populáció egészéhez.

\section{A minta bemutatása}

A minta egészében a nők aránya 68,7\%, míg a férfiak 31,3\%-kal képviseltetik magukat. Ez markáns nőtöbbletet jelez, s ennek mértéke meghaladja az országos értékeket (az Oktatási Hivatal statisztikái alapján a 2017/2018-as tanévben a női hallgatók aránya $52 \%$ volt az összes képzési szintet megvizsgálva, a nappalisok között pedig ez az arány 51\%-os - Internet 2). Ez a Debreceni Egyetem 
képzési struktúrájával is magyarázható, de sokkal inkább érdemes reflektálni arra a tényre, hogy minden bizonnyal ez az érték a roma nők oktatási expanziójával kapcsolható össze.

A lakóhely szerinti megoszlás alapján a megkérdezettek 37,3\%-a faluról érkezett, tehát a diákok többsége jelenleg városi lakos. A város kategória további bontásával a kisvárosok dominanciája rajzolódik ki (55,2\%), míg a megyeszékhelyen/fôvárosban lakó diákok aránya alacsony (7,5\%). A kapott adatokat a legutóbbi, 2018-ben publikált országos vizsgálat becsléseihez hasonlíthatjuk - ott a roma lakosság egészére nézve a falusi lakosság arányát 37,8\%-ra, a kisebb városokban élőket 32,7\%-ra, a nagyvárosi lakosságot pedig (megyeszékhely és főváros együtt) 38,2\%-ra becsülték (Pénzes, Tátrai és Patrik 2018).( Megjegyzés: A becslés a roma lakosság egészére, és nem a fiatal kohorszra irányult. Fontos lehet az a tény is, hogy a roma lakosság termékenységi mutatói településtípusonként is különböznek.)

Ez alapján azt mondhatjuk, a debreceni roma szakkollégiumok a kisvárosi roma fiatalokat tudták a legeredményesebben megszólítani. Kérdés, hogy ez a megyeszékhelyen élők sajátos oktatási karrierjére utal, vagy pedig arra, hogy tanulmányaikat nem a régióban vagy nem a szakkollégiumi keretek között végzik a fiatalok. A megkérdezettek 85\%-a gimnáziumban végezte középiskolai tanulmányait.

Az etnikai identitás esetében a megkérdezettek több választ is megadhattak. A minta 50,5\%-a vallja magát romának, míg magyar identitással 67\%-uk bír. 16 fó, tehát a minta 23,8\%-a kettős identitással jellemzi magát. A magukat romának vallókon belül (50,5\%) a romungrók vannak többségben $(69,4 \%)$, őket az oláh cigányok követik (22,2\%). A beás és egyéb csoportok jelenléte elenyésző.

A megkérdezettek 92,5\%-a nappali tagozatos hallgató, és 20,9\%-uk költségtérítéses formában tanul. A látogatott szakok változatosak, azonban a humán és pedagógiai jellegű területek százalékos megoszlása magasabb, a műszaki és orvosi területek pedig alulreprezentáltak.

\section{A szociokulturális háttér viæsgálata}

Az egyik legfontosabb szociokulturális háttérváltozónak a szülők iskolai végzettsége tekinthetô. A Magyar Ifjúság 2016 adatbázis alapján az nappali tagozatos hallgatók 55\%-a nem értelmiségi háttérrel bír, tehát egyik szülőnek sincsen diplomája, míg az alapfokú végzettséggel bíró szülők aránya elenyészô, pár százalékos értéket mutat (Bocsi, 2019). A roma szakkollégisták szüleinek iskolai végzettségét a 3. ábra mutatja be.

Ez a megoszlás a roma fiatalok átlagától jóval kedvezőbb képet, a nappali tagozatos hallgatókhoz viszonyítva azonban jelentős lemaradást mutat. Ezen diákok legtöbbje egyértelmúen reziliensnek tekinthető (Ceglédi, 2012), tehát hátrányaik ellenére érték el a felsőoktatást.

A szülók iskolai végzettségének alaposabb vizsgálata azonban arra a tényre hívja fel a figyelmet, hogy a szakkollégiumok társadalmán belül törésvonalak tapinthatók ki az identitás mentén. Khínégyzet tesztet használva ugyanis egyértelmú ( $\mathrm{p} \leq 0,05$, sig.: 0,002 az édesanyáknál és 0,008 az édesapáknál), hogy a kedvezőbb háttérből érkező diákok (közülük kerül a diplomás szülők többsége) között többségben vannak a magukat nem romának vallók. A roma származású diákok esetében az anyák 70\%-ának van alapfokú vagy alacsonyabb végzettsége, míg az apáknál ez az arány kb. $50 \%$.

Ez a Magyar Ifjúság 2016 roma almintájához viszonyítva még mindig kedvezőbb képet mutat, mint az országos átlag (a 15 és 29 életév közötti roma fiatalok esetében az anya iskolai végzettsége a megkérdezett 14 éves korában 88\% esetében volt alapfok vagy az alatt, az apáknál pedig ez az arány $82,5 \%)$. 
3. ábra. Roma szakkollégisták szüleinek iskolai végzettsége ( $N=67$, száąulékban megadva, saját sz̧erkesztés)

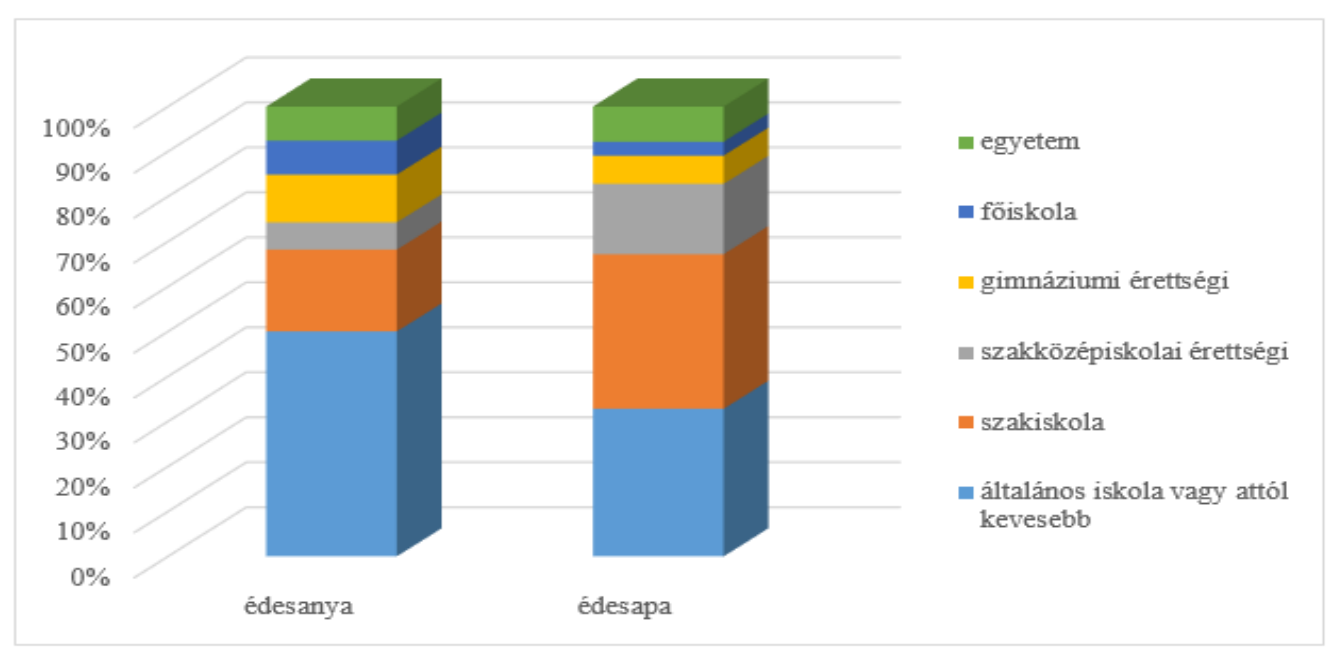

A hátrányos helyzet esetében is hasonló rajzolatot kapunk. Középiskolás korában hátrányos helyzetűnek 28,4\%, halmozottan hátrányos helyzetűnek 34,3\%, míg nem hátrányos helyzetűnek 37,3\% vallotta magát. A kereszttáblás elemzés ebben az esetben is a nem roma identitással bírók kedvezőbb helyzetére utal ( $\mathrm{p} \leq 0,05$, sig.: 0,02$)$. Az egyes szakkollégiumok között szignifikáns eltérések a szociokulturális háttér esetében nem voltak kimutathatók.

A szakkollégiumi mintánkat a szubjektív anyagi helyzet megítélése alapján össze tudjuk hasonlítani a Magyar Ifjúság 2016-os roma almintájával, és a minta egészével (4. ábra).

A 4. ábráról leolvasható, hogy a roma szakkollégisták a jelenlegi anyagi helyzete közelebb van a 8000 fôs minta egészéhez, mint a roma alminta rajzolatához, s a roma identitású szakkollégisták anyagi helyzete valamennyivel kedvezótlenebb, mint a roma szakkollégisták egészének helyzete. Kérdés ugyanakkor, hogy a szakkollégiumi támogatások rendszere milyen mértékben eredményezi ezt a rajzolatot, s milyen volna a hallgatók helyzete e támogatási formák nélkül. Azt azonban joggal valószínúsíthetjük, hogy a roma szakkollégisták a roma populáció magasabb státuszú csoportjaiból érkeznek. A családi háttérnek ezt a mintázatát a szülők iskolai végzettsége kapcsán is láthattuk.

A családban megtalálható könyvek a kulturális tőke fontos részét képezik (Bourdieu, 1978), s gyakori háttérváltozóként használják a gyermekek iskolai teljesítményének előre jelzésekor is. A roma szakkollégisták esetében az otthoni könyvek száma 96, azonban a roma identitás alapján szignifikáns eltérés mutatható ki (ANOVA-teszt, $\mathrm{p} \leq 0,05$, sig.: 0,016 - roma identitás esetében 52 könyv, nem roma identitású szakkollégisták esetében 190 könyv). 
A Magyar Ifjúság adatbázissal való összehasonlítást az 5. ábra mutatja be. A roma identitású szakkollégisták esetében a családi könyvtár körülbelül kétszerese a Magyar Ifjúság 2016 roma almintá- jának. A szakkollégisták esetében azonban a nem roma diákok is messze elmaradnak a hallgatói minta átlagától (350 darab), ami a kulturális tőke felhalmozásának alacsonyabb mértékére utal.

4. ábra. Az anyagi helyzet szubjektiv jellemzése (N=66, 34, 328 és 8000, százalékban megadva. Az utolsó két oszlop a Magyar Ifjúság 2016 alapján készüilt). Forrás: Saját szerkesżtés.

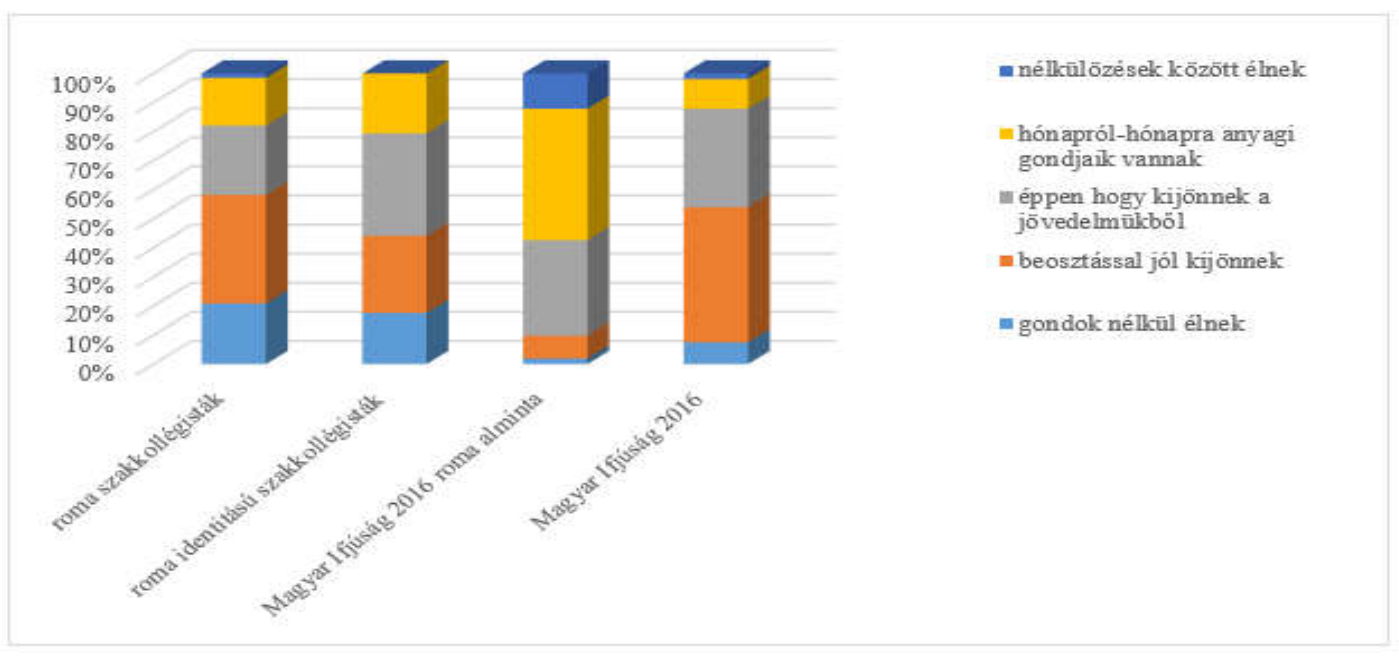

5. ábra. A könyvek sqáma a roma szakkollégisták, valamint a Magyar Ifjúság 2016 családi könyvtárában (darabban megadva*, $N=523,5573,259,33$ és 32). Forrás: Saját szerkesztés

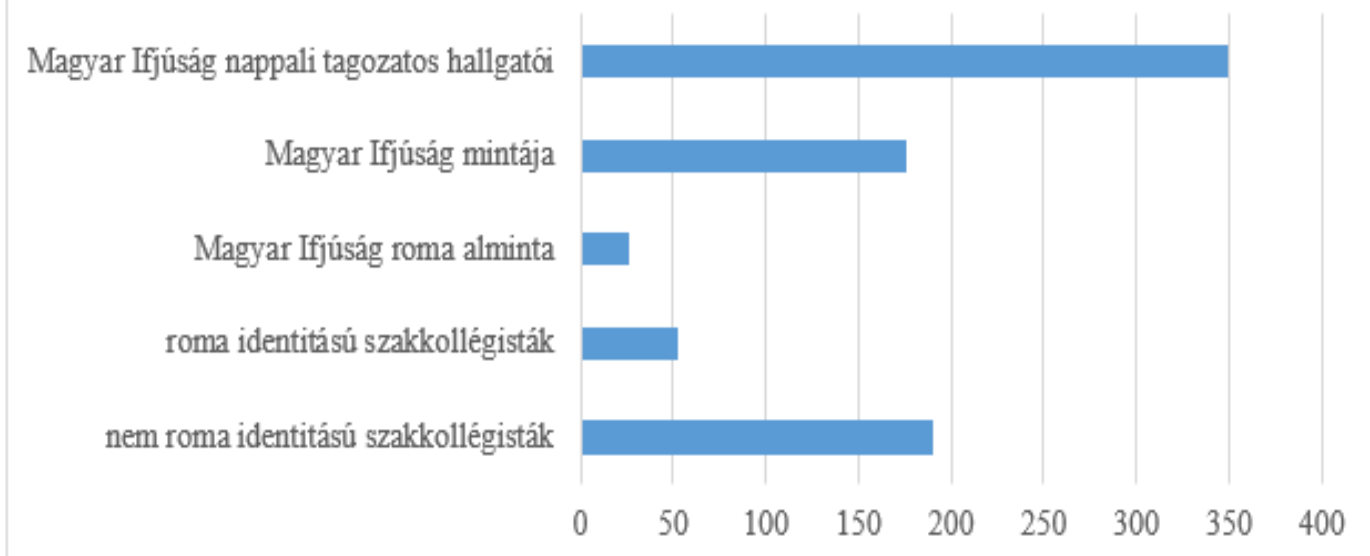

A nem tudja/nincs válaszokat az átlagok értelemszerũen nem tartalmazzák, a nulla értékeket viszont igen. 


\section{A családszerke zet vizsgálata}

Elemzésünk egyik szálát a családszerkezet vizsgálata képezte. A szülók párkapcsolati formáját sok tényező alakítja - a válási ráták az adott közösség érték- és normarendszerébe beágyazottak, éppen úgy, ahogyan a házasodási szokások is. A családszerkezeti törések a fiatalok tanulása, eredményessége szempontjából kockázatot jelenthetnek, ugyanakkor a „klasszikus” modelltől eltérő formákat nem azonosíthatjuk egyértelmúen egy olyan környezettel, amely hátrányt jelent, s a „klasszikus” formák is múködhetnek diszfunk-cionálisan. A roma szakkollégisták családszerkezeti hátterét a 6 . ábra mutatja be. Ha a kapott adatokat a Magyar Ifjúság 2016-hoz (ahol a válás gyakorisága a 14. életév esetében $10 \%$, a roma identitással bírók esetén pedig $12 \%$ volt), vagy pedig a $\mathrm{KSH}$ adataihoz viszonyítjuk (gyermekes családok esetén a „házaspár gyermekkel" forma aránya 2011-ben 83\% volt - Internet 3), akkor azt mondhatjuk, hogy a roma szakkollégisták családszerkezeti mintázatai ha nem is drasztikusan, de valamennyivel magasabb arányban mutatnak sajátos formákat (egyszülős családok, mozaikcsaládok). A családszerkezetet megvizsgálva a roma identitás mentén különbségeket nem találtunk.

\section{A kapcsolati hálók vižsgálata}

A kapcsolati hálók egyfajta erőforrásként is értelmezhetők, és a továbbtanulási döntéseket is befolyásolják - különösen a diplomások jelenléte az, ami fontos kutatási kérdésként jelenik meg a vizsgálatokban. A felsőoktatás klasszikusan középosztálybeli háttérrel bírt, ez azonban a tömegessé válással (illetve bizonyos esetekben politikai intézkedések hatására) megváltozott. Azok a személyek, akik a kapcsolatháló diplomával bíró tagjai, egyrészt elmozdítják a fiatalokat a továbbtanulás irányába, másrészt pedig ,ismerőssé” teszik az egyetemi klímát. A felsőoktatás társadalmi nyitottsága fontos elvárás, s a társadalmi mobilitás magasabb rátájával is összefügg. Kutatási kérdés lehet, hogy az utóbbi években tapasztalható bezáródás (Berlinger-Megyeri, 2015), melynek okai összetettek, vajon hogyan érintik a roma szakkollégiumokat.

\section{6. ábra. A szakkollégisták családszerkezeti jellemzöi ( $N=66$, százalékban megadva). Forrás: Saját szerkesztés.}

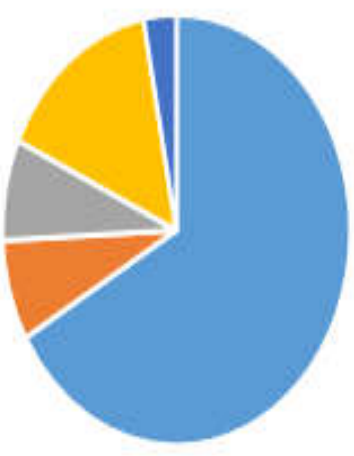

- szüleim házasok voltak, egyūtt éltek és együtt neveltek engem

- szüleim nem voltak házasok, együtt éltek és együtt neveltek engem

- édesanyám és nevelö/mostohaapa nevelt 
7. ábra. A kortárs kapcsolatok etnikai mintázata (N=64 fö, százalékban megadva). Forrás: Saját szerkesztés.

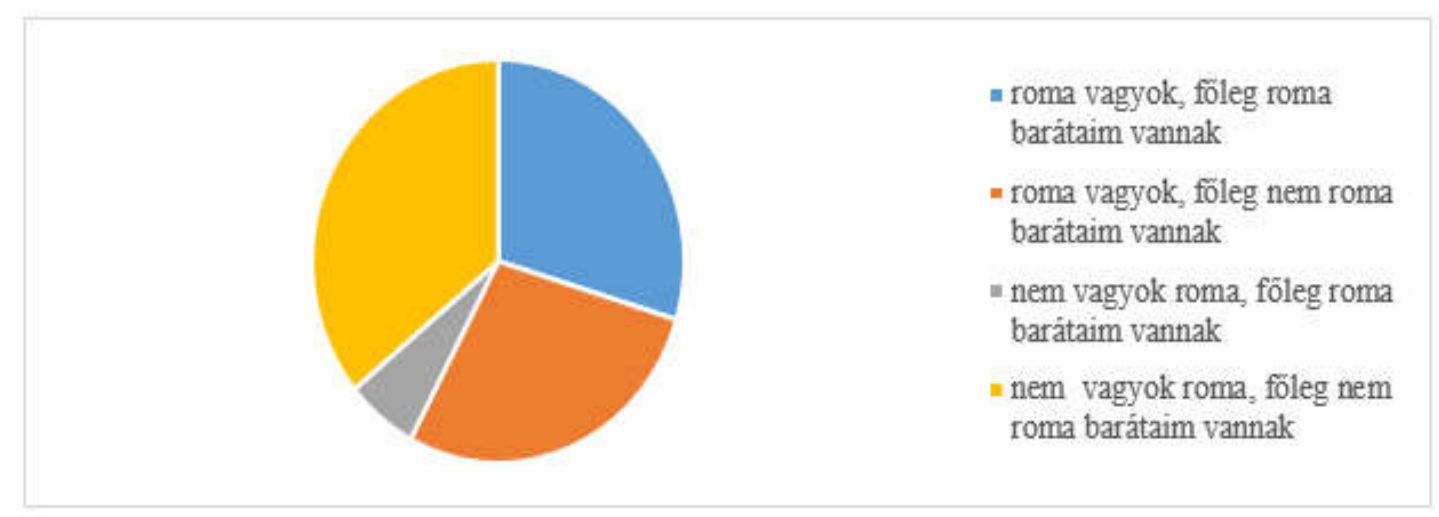

Ha a kapcsolati erőforrásokat megvizsgáljuk, azt találjuk, hogy a mintánkat alkotó hallgatók számára jóval korlátozottabban állnak a rendelkezésre.

Arra a kérdésre, hogy van-e diplomás a családjában, rokonságában vagy baráti körben, a megkérdezettek túlnyomó többsége nemmel válaszolt. A diploma-sok legmagasabb aránya az unokatestvérek (38,5\%), szomszédok (13,5\%), pár/élettárs/házastárs (13,5\%) és egyéb rokon esetében figyelhetők meg (18,5\%). A kapcsolati hálókkal a roma identitás nem mutatott összefüggést.

A roma szakkollégiumok a sajátos lakhatási körülmények, illetve a közösségi programok miatt speciális kortárs kapcsolati mintázatokat produkálnak, amit a 7. ábra mutat be. A 7. ábrán látható, hogy bár a legnagyobb százalékos eloszlásokat az etnikailag homogén kapcsolathálók adják, a szakkollégisták 34\%-a esetében az etnikai határokon átnyúló networköket találhatunk. Ennek nagyobb hányadát túlnyomórészt azok a roma fiatalok jelentik, akik leginkább nem roma kortársaikkal barátkoznak, bár magukat romának vallják $(28 \%)$, azonban hat százalékos nagyságrendben megjelenik ennek a mintának az ellentettje is. A szakkol- légiumok tehát teret adnak a baráti kapcsolatok etnikailag kevert mintázatainak.

\section{A szakekollégiummal való kapcsolat}

Fontos kérdés (már csak a toborzás szempontjából is), hogy a szakkollégisták honnan szereztek információt az oda való bejutás lehetőségéről és a szakkollégium múködéséről. A nyolcadik ábráról olvashatók le a kapott adatok. Láthatjuk, hogy az internetes felületek, weblapok, toborzó rendezvények alig jelennek meg a válaszokban, ami lényeges visszacsatolás lehet a szervezetek számára. A legfontosabb információforrásnak a személyes kapcsolathálók (barátok, családtagok) mutatkoznak, illetve - korlátozott mértékben - megjelenik a pedagógusok hatása. Arra a kérdésre, hogy korábban ismert-e szakkollégistákat, a megkérdezettek 43,3\%-a felelt igennel. A legnagyobb arányban a volt iskolatársak, barátok és testvérek jelennek meg a válaszokban (a barátok esetében maximum 12 fővel, ami a legmagasabb értéket jelenti). Mindezek ugyanakkor arra is utalnak, hogy a szakkollégisták több mint felének nincsen előzetes információja az intézmények múködéséról, ami az első, beilleszkedési periódus fontosságára hívja fel a figyelmet. 
8. ábra Információ-források a szakekollégiummal kapcsolatban. „Hol hallott elöször a szakkollégiumról?” (N=65, föben megadva). Forrás: Saját szuerkesz̨tés.

\begin{tabular}{|r|r|r|r|r|}
\hline baráttól, ismeröstổ \\
családtagtó1
\end{tabular}

\section{Korábbi tanulmányi tapasztalatok}

A megkérdezettek általános iskolai tanulmányainak gyakran (31,3\%-ban) volt a helyszíne olyan intézmény, amelyben a hátrányos helyzetűek képezték a diákok többségét, míg 45,3\% úgy látja, hogy a hátrányos és nem hátrányos helyzetú diákok aránya körülbelül megegyezett. Ebben az adatban egyrészt a roma lakosság szegregációjának magasabb aránya, illetve az oktatási rendszer szelektivitása köszön vissza. A szakirodalom alapján tudjuk, hogy az integrált oktatás esetében a pedagógiai hozzáadott érték magasabb, és hogy a jól teljesítő tanulók iskolai teljesítménye a heterogén összetételü osztályokban a legkedvezőbb (ahol a rosszabbul teljesítő diákok aránya 10 és 25\% között van - összefoglalja: Fejes, 2013). Kutatásunkban a roma etnikai identitás és az iskolai közösség heterogenitása között szignifikáns különbség nem volt kimutatható. A szakkollégista diákok 72,7\%-a nyilatkozott úgy, hogy általános iskolai évei alatt semmilyen támogatási formában nem részesült. A legked-vezőbb elemszámokat az Útravaló Ösztöndíjprogramnál, illetve az önkormányzati támogatásoknál találjuk (mindössze tíz, illetve hat fővel). Az iskolán belüli segítséget leggyakrabban az osztályfőnökök és a szaktanárok jelentették (19 és 11 fövel), az iskolai szociális munkás, az iskolapszichológus és a gyermekvédelmi szakemberek a válaszokban egyáltalán nem jelentek meg. Az általános iskolában kapott segítségek leggyakoribb tartalmát a továbbtanulással kapcsolatos információk, a tanulásban nyújtott támogatás és az adminisztrációs segítség jelentette (maximum 14 fövel). Az így kirajzolódó kép arra utalhat, hogy a diákok az alapfokú oktatásban valamilyen oknál fogva nem tudják kiaknázni számukra elérhető lehetőségeket, nincs információjuk az elérhető támogatásokról, a segítő szakemberek iskolán belüli jelenléte pedig nem volt számukra érzékelhető.

A középiskolákkal kapcsolatban más mintázatokat kapunk (9. ábra). Értelemszerűen csökken azoknak az intézményeknek az aránya, ahol hátrányos helyzetú diákok többségben vannak (20,6\% és a legmagasabb értéket a hátrányos helyzetű diákokat csak kisebb arányban befogadó intézmények kapják (55,6\%). 
9. ábra. A középiskola jellemzése és az etnikai identitás kapcsolata ( $N=63$ fö). Forrás: Saját szerkesżés.

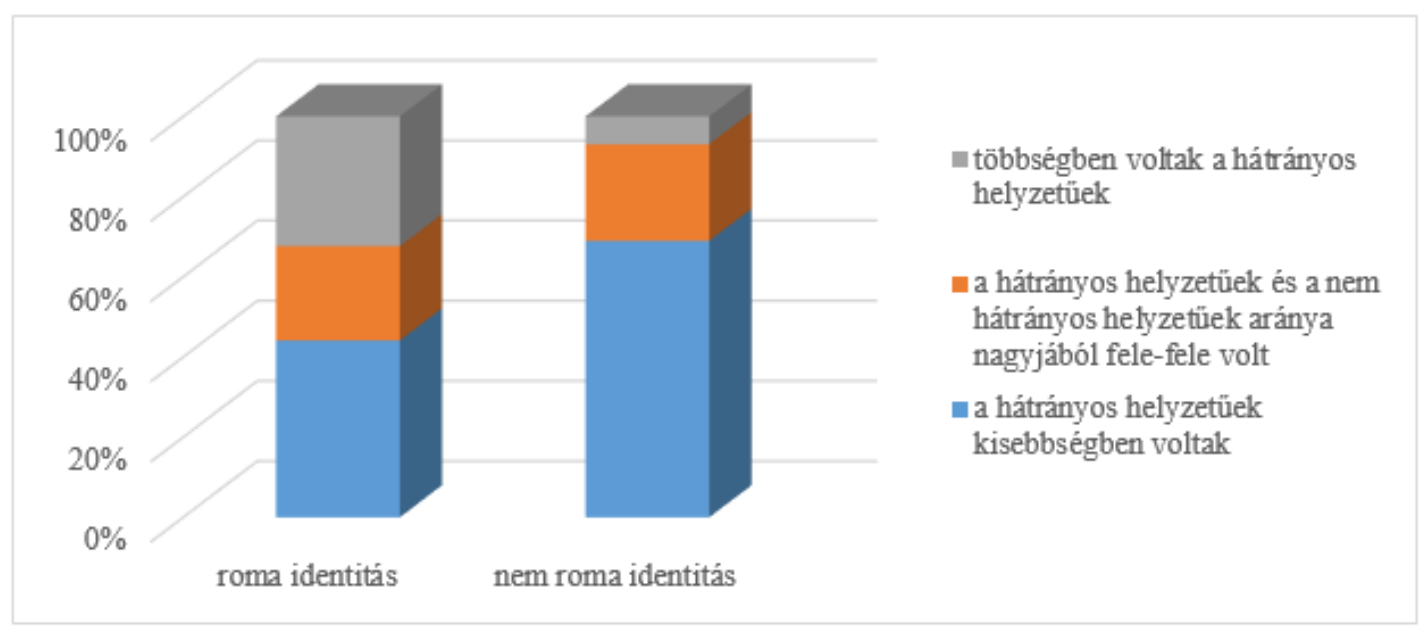

Ez arra utal, hogy a szakkollégista diákok egy jelentôs része nem a felsőoktatásban kerül először olyan intézményi környezetbe, ahol magasabb státuszú diákokkal találkozik, hanem az alapfokközépfok közötti váltás jelent számára fordulópontot. A középiskola típusa és a roma identitás közötti kapcsolat azonban arra utal (khínégyzet próba, $\mathrm{p} \leq 0,05$, sig.: 0,036), hogy ez a korai váltás gyakoribb a nem roma szakkollégistáknál (9. ábra). A roma identitású szakkollégisták esetében ezt a „váltást” sokkal inkább a felsőoktatás fogja jelenteni. A hátrányos helyzetûek többségét felmutató középfokú intézményeket két fő kivételével a roma diákok látogatták.

A középfokon igénybe vett támogatási formák százalékos aránya 54,7\%-ra nőtt, és az igénybe vevők elemszáma is emelkedett (hét fó: önkormányzati támogatások, 13 fố: Útravaló Ösztöndíjprogram, tíz fơ: AJTP, négy fő: AJK). A segítséget nyújtó személy ebben az esetben is leginkább az osztályfőnök, azonban megemelkedik a szaktanárok aránya, és középfokon már megjelennek egy-egy említéssel az iskolapszichológusok és az iskolai szociális munkások is. A tizedik ábráról leolvasható, hogy az egyes segítségtípusoknak az említési gyakorisága magasabb, és hét fő esetében már a személyes problémák megoldása is megjelent (ez az alapfok esetében egy esetben fordult eló).

Mindennapi problémák esetében a leggyakoribb segítő személynek az osztálytársak bizonyultak (40 fő), azonban 16 esetben az osztályfőnök, tíz esetben a szaktanár is megjelenik a válaszokban.

Ez már a pedagógusok erōteljesebb szerepére utal a reziliens karrierek esetében. A segítség leggyakrabban tanácsadást, bátorítást és a problémák megbeszélését jelentette, de több esetben jelent meg a tanulási támogatás és akár az anyagi segítség is. Tíz fô számolt be tanulási nehézségekről a középiskolás évei alatt, amelynek megoldásaként a több tanulás és a magántanár alkalmazása jelent meg - de gyógypedagógusok vagy pszichológusok nem.

A kortárskapcsolatok jelentőségre hívja fel a figyelmet a network-szakirodalomra hivatkozva Hajdu-Kertesi-Kézdi (2014). Az eltérō társadalmi státusú társadalmi csoportok között a csoportközi kapcsolatok védőfaktorként múködnek és átsegítik a nehezebb helyzetben levő alacsony társadalmi státusú csoportok tagjait az életesélyeik szempont- 
jából sorsdöntő küszöbértékeken, így például a lemorzsolódás elkerülésében.

A középiskolák többsége (37 fő szerint) nyújtott segítséget az érettségire való felkészülésben (ez viszont azt is jelentette egyúttal, hogy a diákok majd fele úgy érezte, hogy ilyen jellegű segítséget nem kapott az intézményben).

Erre a felsőoktatásba való bekerülési feltételek miatt minden bizonnyal szükség van a hátrányos helyzetű és/vagy roma fiatalok esetén. Az iskolák nyújtotta segítség egyéb kategóriájában gyakran megjelenik a válaszok között az ingyen korrepetálás, amelynek a helyszíne akár a pedagógus saját lakása is lehet. A felkészülés kritikus pontjait az idegen nyelv tanulása és a reál tárgyak képezték.

A diákok 36,4\%-a volt kollégista a középiskolás évei alatt (ez az arány hasonlít a falusiak arányához).
A kollégiumi bentlakás annak komplex pedagógiai hatása miatt rendkívül fontos a hátrányos helyzetú fiatalok társadalmi mobilitása esetében. Ezzel a válaszadók is tisztában vannak, hiszen az alapvető ellátáson kívül (lakhatás, étkezés, higiénia) 45\%-ban jelennek meg a szabadidőre vonatkozó, illetve egyéb válaszok, mikor a kollégiumok nyújtotta segítség tartalmára kérdeztünk rá. Iskolán kívüli segítséget ezekben az években saját bevallása szerint négy fố kapott családvédelmi szakemberektől.

\section{Tanulási motivációk}

A tanuláshoz füződő viszonyt két kérdésblokk elemezte. Az első egy többválaszos kérdés volt, ahol a továbbtanulás indokait kellett megadni. A kapcsolódó adatokat a 11. ábra mutatja be.

10. ábra. A középiskolás évek alatt kapott segitség tartalma ( $N=67$ fö). Forrás: Saját szerkesztés.

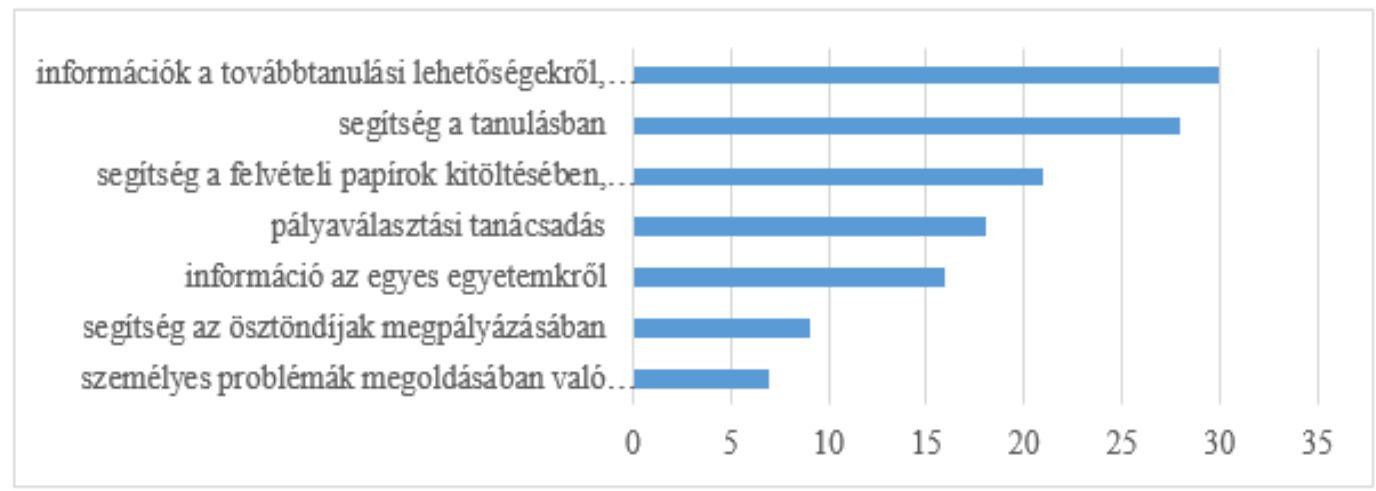

11. ábra. A továbbtanulás indokai (N=67, föben megadva). Forrás: Saját szerkesztés.

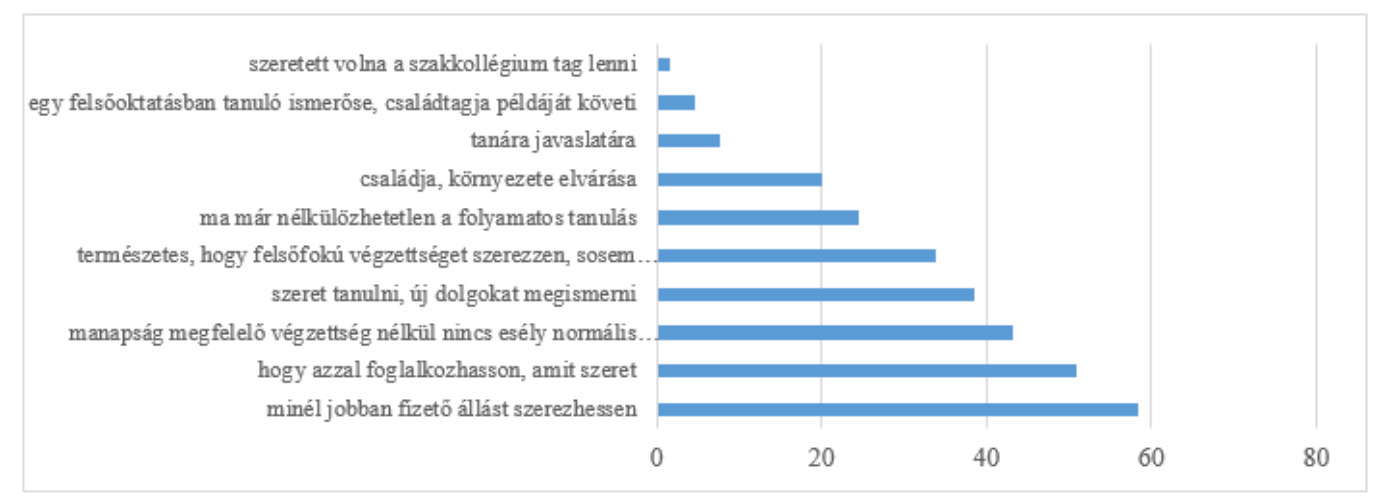


A továbbtanulás anyagiakban megtérülő hasznosságát, tehát egyfajta materiális motivációt jelez a „minél jobban fizető állást szerezzen” kijelentés magas választottsága, és az utilitarista meg-közelítés fontosságát jelzi a harmadik pozí-cióban lévő állítás is. A tudásvággyal és az önkiteljesítéssel kapcsolatos itemek is kedvező pozícióban vannak, ugyanakkor a mintakövetés, környezeti elvárások nem voltak jellemzőek, ahogyan a szakkollégiumi tagság sem.

Egy másik kérdésblokk a pálya- és egyetemválasztás indokait ötfokú skálával mérte fel. A kapott eredményeket a 12. ábrán láthatjuk. A kapott rajzolatokban itt az önkiteljesítés és a praktikus elemek keveredését tapasztalhatjuk. A munkaerő-piaci elhelyezkedés fontos motivációs bázis. Az egyetem presztízse a lista közepén foglal helyet. A családi minták ereje gyenge, és a szakkollégium megléte sem tekinthető domináns intézményválasztási motivációnak.

A kérdőív utolsó eleme egy nyitott kérdést tartalmazott, amelyben a diákok kifejthették, hogy milyen tényezők segítenék nagyobb mértékben a hátrányos helyzetû fiatalok középiskolai tanulmányait. A kérdésre tizenkét válasz érkezett. Ezek leginkább a mentorprogramok és a pályatanácsadás fontosságát, illetve az egyéni fejlesztések szükséges- ségét hangsúlyozták, de megjelentek a jelenlegi oktatási rendszer kritikus pontjai is: egyrészt a nyelvtanítás magasabb hatásfokát látják szükségesnek, másrészt pedig a tanári szakma kontraszelektált voltát emlitették, illetve a pedagógusok módszertani kultúrájának fejlesztését tartották fontosnak.

\section{Összegzés}

A roma szakkollégiumban tanuló roma és nem roma identitású hallgatók között törésvonal van a hátrányos helyzet, a szociokulturális háttér, az anyagi helyzet szubjektív jellemzőit tekintve. A nem roma identitású hallgatók kedvezőbb helyzetben vannak ezeken a területeken. A családszerkezetet, a kapcsolati hálót tekintve ilyen különbséget nem találtunk.

A hallgatók társadalmi hátterére jellemző, hogy a roma fiatalok magasabb státuszú csoportjaiból érkeztek. Ezt tükrözi a kisvárosi lakóhely és a szüleik iskolai végzettsége is. Kiemeljük, hogy a hallgatók többsége gimnáziumból érkezett a felsőoktatásba, tehát nem a szakma szerzése volt számukra elsődleges szempont az általános iskola utáni években.

12. ábra. A pálya-és egyetemválasżás indokai ( $N=67$, ötokozatú skálával mérve). Forrás: Saját szerkesztés.

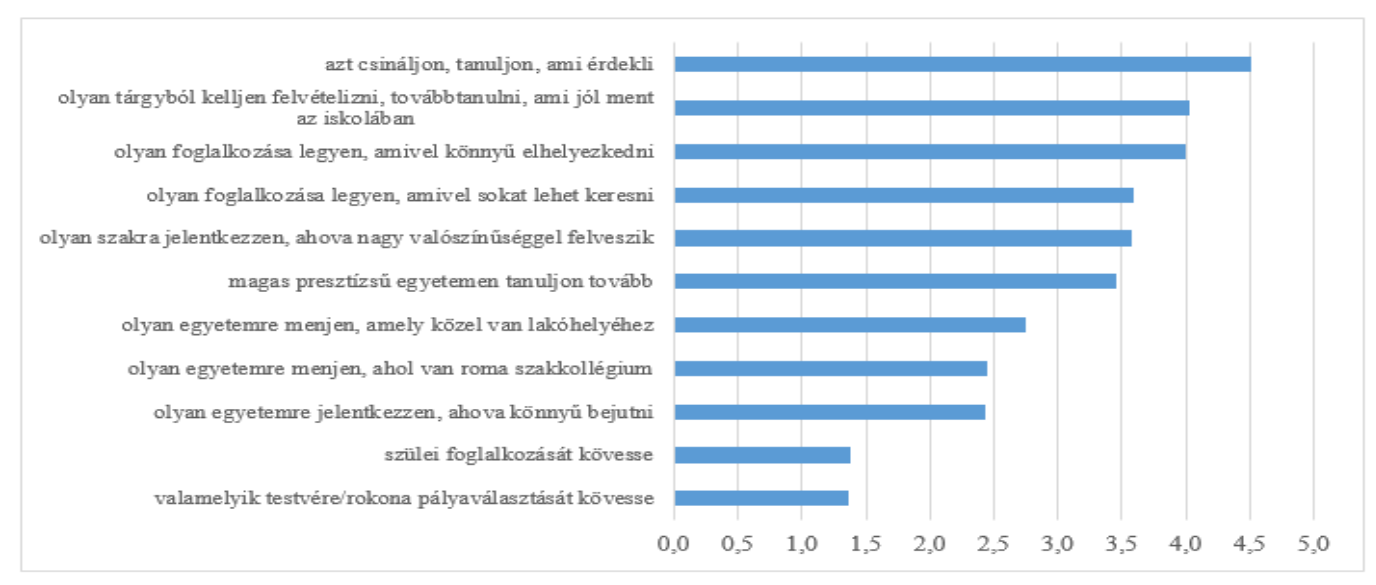


Az általános iskolai tanulmányaik során a hallgatók jelentős része nem kapott sem anyagi, sem személyes segítő támogatást. A személyes segítség többnyire a felvételihez szükséges adminisztrációt jelentette, illetve a tanulás segítését. Ezzel szemben a középiskolában jóval több anyagi illetve személyes segítségről számoltak be. A személyes segítség nagyobb mértéke összefügghet azzal is, hogy a válaszadók szerint a középiskolák többsége hátrányos helyzetűeket kisebb arányban fogadott be. Az anyagi támogatások között az ösztöndíjprogramok kiemelendők, a személyes segítésben pedig a tanulás segítése az osztályfőnök, szaktanárok közremúködésével, akár tanórán kívüli tevékenység keretében is.

Az Arany János programok tanulói körében végzett kutatás kimutatta, hogy „minél alacsonyabb státuszú a diák, annál több a tanári segítségnyújtás. Az alsó társadalmi csoportokhoz tartozók körében az általános iskolai, a középiskolai és a kollégiumi tanárok is nagyobb szerepet játszanak, mint a középső vagy felső csoportoknál. Ez utóbbiaknál a szülők, a család dominánsabb szerepet tölt be a tanuló életében.” (Fehérvári, 2018, 140.) Jelentős mértékú az osztálytársak egymás iránti segítókészsége, ami akár a tanulási sikereket is előmozdíthatja. A diákok kisebb hányada élt kollégiumban a középiskolás éveiben, aminek jelentős szerepet tulajdonítottak a megkérdezettek - az alapvető szükségleteik kielégítésén túl - a szabadidő eltöltésében.

A hallgatók továbbtanulási motivációit tekintve az érdeklődés mellett a tantárgyak teljesítésének minősítését is figyelembe vették. Ahogy a kutatások eredményei mutatják (Liskó, 2005) a gyerekek családi, ismeretségi, és lakóhelyi környezetében nincsenek olyan mobilitási modellek, amelyek számukra mintát szolgáltathatnának. Az általunk megkérdezettek között is kevéssé volt jellemző a továbbtanulásban, hogy a szülő, a testvér, vagy más rokon példáját követték volna. Családjukból min- den bizonnyal elsőként kerültek be egy felsőoktatási intézménybe.

A hallgatók a hátrányos helyzetú tanulók iskolai sikerességének előmozdításában fontosnak tartják a pályaválasztási tanácsadást, az egyéni fejlesztést, a mentorprogramokat. A pedagógusok módszertani kultúráját, a nyelvtanítás megújitását is kiemelték, mint fejlesztendő területet. A szakkollégiumok éppen a hallgatók által az iskolai sikeresség előmozdításában fontosnak tartott programokat pályaválasztási tanácsadás, egyéni fejlesztés, mentorprogram- valósítják meg, ezzel jelentősen hozzájárulnak a roma diplomások számának növeléséhez.

A tanulmányban bemutatott kutatás a Kopp Mária Intézet a Népesedésért és a Családokért (KINCS) támogatásával készüilt

\section{Irodalom}

Berlinger, E. \& Megyeri K. (2015). Mélyszegénységből a felsőoktatásba. Közgazdasági Szemle, 62(6). 674-699.

Bernát a. (2018). A magyarországi romák társadalmi integrációja a 2010-es években. In: Társadalmi riport 2018, Budapest, Tárki. 144-165

Bocsi V. (2019). First Generation Students in the Hungarian Higher Educational System. Central European Journal of Educational Research, 2(1). 5365.

Bourdieu, P. (1978). A társadalmi egyenlótlenségek üjratermelódése. Gondolat Kiadó, Budapest.

Ceglédi, T. (2012). Reziliens életutak, avagy a hátrányok ellenére sikeresen kibontakozó iskolai karrier. Szociológiai Szemle, 22(2): 85-110.

Fehérvári A. (2018): Az Arany János Program tanulói. In: Fehérvári A., Varga A. (szerk.): Rez̧iliencia és inklúzió az. Arany János Programokban. Pécsi Tudományegyetem. Bölcsészettudományi 
Kar Neveléstudodmányi Intézet Romológia és Nevelésszociológia Tanszék, Wlislocki Henrik Szakkollgéium, Pécs 119-158.

Fejes J. B. (2013). Miért van szükség deszegreációra? In: Fejes J. B. és Szű́cs N. (szerk): $A$ szegedi és a hódmezóvásárbelyi deszegregációt támogató hallgatói mentorprogram. Belveder Meridionale, Szeged, 15-35.

Forray R. K. és Hegedús T. A. (2001). Oktatáspolitikai változások a cigány gyerekek iskoláztatásában. In. Andor M. (szerk): Romák és oktatás. Pécs: Iskolakultúra, 13-30.

Györgyi Z. (szerk.) (2011). Korlátok közö̈tt szabadon. Demográfiai folyamatok és helyi oktatáspolitikák. Budapest: Oktatáskutató és Fejlesztő Intézet

Hajdu T. , Kertesi G. és Kézdi G. (2014). Roma fiatalok a középiskolában. Beszámoló a TÁRKI Életpálya-felmérésének 2006 és 2012 közötti hullámaiból. In: Társadalmi riport, 2014. TÁRKI, Budapest, 265-302.

Hegedûs R. (2018). Hátrányos helyzetüek a közép-és felsöoktatásban. Hátrányos helyzetü tanulók középiskolai teljesitménye és felsöoktatásba veló bejutásuk. jellemzóí, különös tekintettel a területi különbségekere. $\mathrm{PhD}$ értekezés. Debreceni Egyetem BTK, Debrecen

Híves T. (2018): Arany János Programok és térségi összefüggéseik. In: Fehérvári A. - Varga A. (szerk.): Reriliencia és inkluizió az. Arany János Programokban. Pécsi Tudományegyetem Bölcsészettudományi Kar Neveléstudományi Intézet Romológia és Nevelésszociológia Tanszék, Wlislocki Henrik Szakkollégium, Pécs 89-118.

Kemény I., Janky B. és Lengyel G.(2004). A magyarországi cigányság 1971-2003. Budapest: Gondolat Kiadó

Kertesi G. és Kézdi G. (2008). A roma és nem roma fiatalok középiskolai továbbtanulása. Első eredmények a TÁRKI-Educatio Életpályafelmérése alapján. In: Kolosi T. - Tóth I. Gy. (szerk.): Társadalmi Riport 2008. TÁRKI Budapest 344-362.
Kertesi G. és Kézdi G. (2016). A roma fiatalok esélyei és az iskolarendszer egyenlőtlensége. MTA KRTK Közgazdaságtudományi Intézet, Budapest.

Web: $\quad$ https://mta.hu/data/dokumentumok/ egyeb dokumentumok/2016/BWP1603\%20K G\%20KG.pdf letöltés ideje: 2020. 09. 15.

Liskó I. (2002). Cigány tanulók a középfokú iskolákban. Kutatás közben sorozat, 234. kötet. Web: http://ofi.hu/sites/default/files/ attachments/234 liskociganykozepfok.pdf. letöltés ideje: 2020. 08. 14.

Liskó I. (2005). A roma tanulók középiskolai továbbtanulása. Felsőoktatási Kutatóintézet, Budapest Web. https://ofi.hu/sites/default/files/ attachments/268 lisko_cigkozep foktovabbtanul.pdf letöltés ideje: 2020. 08. 14.

Magyar Ifjúság Kutatás 2016. Web: http://www.ujnemzedek.hu/sites/default/files Lmagyar ifjusag 2016 a4 web.pdf letöltés ideje: 2020. 09. 12.

Pénzes J., Tátrai P. és Pásztor I. Z. (2018). A roma népesség területi megoszlásának változása Magyarországon az elmúlt évtizedekben. Területi Statisztika, 58(1): 3-26.

Roma Szakkollégiumi Charta. Web: http:/ /krszh.hu/dokumentumok/ letöltés ideje: 2020. 09. 14.

Szabóné Kármán J. (2008). A roma/cigány népesség helyzete. In. Kopp Mária (szerk): Magyar lelkiállapot 2008. Budapest: Semmelweis Kiadó, 415-427.

Szemenyei M. (2018): Az Arany János programok szakmapolitikai szabályozása . In: Fehérvári A. Varga A. (szerk.): Reriliencia és inklizió az. Aramy János Programokban. Pécsi Tudományegyetem Bölcsészettudományi Kar Neveléstudományi Intézet Romológia és Nevelésszociológia Tanszék, Wlislocki Henrik Szakkollégium, Pécs 47-64.

Wáli István Református Cigány Szakkollégium Szakmai Programja. Web: http://www.wisz.hu /tartalom/dokumentumok/14 wisz szp modszerta 
ni-eiras 20181001 honlapra 1.pdf letöltés ideje: 2020.09.12.

Internetes hivatkozások

I1.:

http://romagov.hu/felzarkozas/\#1490614724723c325ef5e-ec90.letöltés ideje: 2020.07.17.
I2.:https://www.oktatas.hu/felsooktatas/kozerdek u adatok/felsooktatasi adatok kozzetetele/felsoo ktatasi statisztikak. letöltés ideje: 2020. 08. 17.

I3:https://www.ksh.hu/docs/hun/xftp/idoszaki/ nepsz2011/nepsz_16 2011.pdf _. letöltés ideje: 2020. 08. 17. 